\title{
Pathogen Exclusion Verification Method
}

National Cancer Institute

\section{Source}

National Cancer Institute. Pathogen Exclusion Verification Method. NCI Thesaurus. Code C158366.

The technique by which the vendor or sponsor ensures that the animals are free from specified pathogens. 